\title{
The Effect of Storage at Different Temperatures on Cholinesterase Activity in Human Serum
}

\author{
By J.R. Huizenga, K. van der Belt and C. H. Gips
}

Hepatochemical Laboratory, Division of Hepatology, Department of Medicine, State University Hospital, Groningen, The Netherlands

(Received March 2/June 25/November 19, 1984)

Summary: The effect of storage on the catalytic concentration of cholinesterase and on the reference values of cholinesterase in human serum were studied. When serum was stored at room temperature $\left(20^{\circ} \mathrm{C}\right)$, at $4^{\circ} \mathrm{C}$ and at $-20^{\circ} \mathrm{C}$ (one year) there was no change in catalytic activity. Even after nine times freezing and thawing (over nine weeks) the catalytic activity was unaffected.

The average reference value was significantly higher for males than for females $(3.11 \pm 0.57$ vs $2.50 \pm$ $0.43 \mathrm{kU} / \mathrm{l})$.

\section{Einfluß der Aufbewahrung bei verschiedenen Temperaturen auf die Aktivität der Cholinesterase im menschlichen} Serum

Zusammenfassung: Der Einfluß der Probenverwahrung auf die katalytische Konzentration von Cholinesterase und auf die Referenzwerte von Cholinesterase im menschlichen Serum wurde untersucht. Aufbewahrung bei Raumtemperatur $\left(20^{\circ} \mathrm{C}\right.$ ), bei $4^{\circ} \mathrm{C}$ und bei $-20^{\circ} \mathrm{C}$ (ein Jahr lang) verursachte keine Änderung der katalytischen Aktivität. Auch nach neunmaligem Einfrieren und Auftauen (während neun Wochen) war die katalytișche Aktivität unverändert.

Der mittlere Referenzwert war für Männer $(3,11 \pm 0,57 \mathrm{kU} / \mathrm{l})$ signifikant höher als für Frauen $(2,50 \pm 0,43 \mathrm{kU} / 1)$.

\section{Introduction}

After the start of the orthotopic liver transplantation programme at The University Hospital Groningen in 1979 , the need arose for a rapidly and easily determined parameter for the synthesis function of the liver.

The enzyme cholinesterase (EC 3.1.1.7) appeared to be suitable for this purpose (1), since it is probably synthesized exclusively in the liver (2). Apart from the liver, cholinesterase is also found in plasma, serum, pancreas, kidney, heart, intestinal mucosa, skin and brain tissue.

Cholinesterase hydrolyses choline esters according to the following reaction:

$$
\text { acylcholine }+\mathrm{H}_{2} \mathrm{O}=\text { choline }+ \text { corresponding acid. }
$$

Besides the value of cholinesterase in testing liver synthesis function, liver cholinesterase is also known to be a sensitive parameter in cases of intoxication with organophosphorus compounds, e.g. parathion, malathion and carbamates $(2,3)$.

It is known that the activity of several enzymes is influenced by storage. In this study, the effect of storage at room temperature $\left(20^{\circ} \mathrm{C}\right)$, at $4^{\circ} \mathrm{C}$ and at $-20^{\circ} \mathrm{C}$ on the catalytic concentration of cholinesterase was evaluated.

Despite the fact that intra-individual differences are small, the reference values for catalytic activity cover a wide range. Therefore, we also compared the reference values with those in the literature, using acetylthiocholine iodide as substrate $(4-6)$. 


\section{Method}

The catalytic concentrations were measured using a kinetic test (Boehringer Mannheim GmbH, cat. no. 124117) with acetylthiocholine iodide as substrate (7). The time ( $t)$ in seconds required for an increase in absorption of $\Delta \mathrm{A}=0.100$ was measured using a Vitatron DCP Colorimeter (Meyvis, Bergen op Zoom, Netherlands) at $412 \mathrm{~nm}$.

The final concentrations in the test were:

$50 \mathrm{mmol} / 1$ phosphate buffer; $\mathrm{pH} 7.2$

$0.25 \mathrm{mmol} / 1$ 5,5-dithiobisnitrobenzoic acid

$5 \mathrm{mmol} / \mathrm{l}$ acetylthiocholine iodide

Sample: $20 \mu \mathrm{l}$ peripheral venous serum.

\section{Calculation:}

catalytic concentration $U / 1\left(25^{\circ} \mathrm{C}\right)=\frac{70376}{t}$. A table goes with the kit.

\section{Results}

\section{Precision}

The data of within and between batch precision, determined in two serum samples, are summarized in table 1.

The coefficient of variation ranged between 1.6 and $2.1 \%$.

\section{Room temperature}

Assays were performed in nine experiments at room temperature $\left(20^{\circ} \mathrm{C}\right)$ after $1,2,4,5,6,7,8,30,48$ and up to 50 hours of storage (fig. 1).

After $50 \mathrm{~h}$ storage there was no change in catalytic activity.

\section{Storage at refrigerator temperature $\left(4^{\circ} \mathrm{C}\right)$}

In six experiments cholinesterase assays were performed after 1, 2, 3, 4, 7, 8 and 9 days of storage (fig. 2).

There was no difference in catalytic activity after 9 days storage.

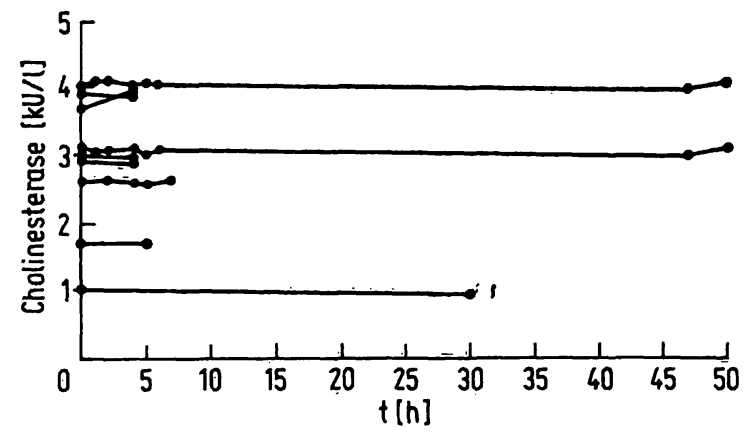

Fig. 1. Influence of storage for up to $50 \mathrm{~h}$ at $20^{\circ} \mathrm{C}$ in nine experiments.

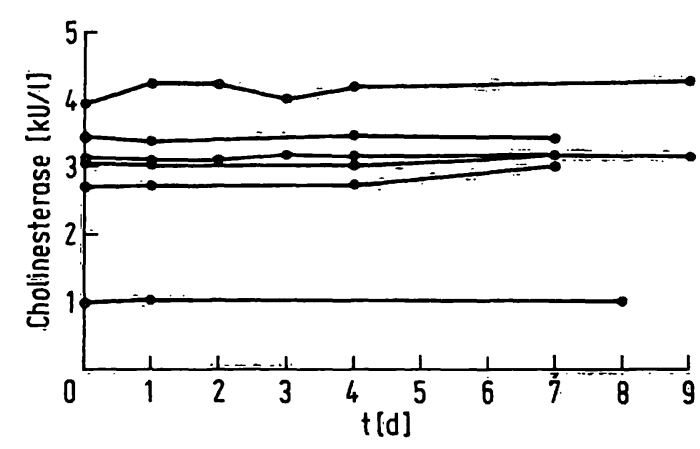

Fig. 2. Influence of storage for $7-9$ days at $4^{\circ} \mathrm{C}$ in six experiments.

\section{Storage at $-20^{\circ} \mathrm{C}$}

Assays were performed in two experiments after 1, 2, $3,4,5,6,7,8$ and 52 weeks of storage (fig. $3 \mathrm{a}$ ).

The serum samples of two control persons were thawed and frozen again each week for nine weeks; every week the catalytic activity was determined (fig. 3b).

The catalytic activity was unaffected in all experiments.

Cholinesterase catalytic concentration in serum of healthy human controls

Catalytic activity was determined in the sera of 77 healthy controls (tab. 2). There were $41 \mathrm{men}$ aged $18-60$ (median 33) and 36 women aged 18-46 (median 24).

Tab. 1. Precision of the assay of cholinesterase catalytic concentration within and between batches determined in two serum samples (CV: coefficient of variation).

\begin{tabular}{|c|c|c|c|c|c|c|c|}
\hline \multirow[t]{2}{*}{ n } & \multicolumn{4}{|c|}{ Within series } & \multicolumn{3}{|c|}{ Between series } \\
\hline & $\begin{array}{l}\text { mean } \\
(\mathrm{kU} / \mathrm{l})\end{array}$ & $\begin{array}{l}\text { range } \\
(\mathrm{kU} / \mathrm{l})\end{array}$ & $\begin{array}{l}\text { CV } \\
(\%)\end{array}$ & & $\begin{array}{l}\text { mean } \\
(k \dot{U} / \mathrm{l})\end{array}$ & $\begin{array}{l}\text { range } \\
(\mathrm{kU} / \mathrm{l})\end{array}$ & $\begin{array}{l}\text { CV } \\
(\%)\end{array}$ \\
\hline $\begin{array}{l}26 \\
24\end{array}$ & $\begin{array}{l}2.15 \\
4.11\end{array}$ & $\begin{array}{l}2.06-2.21 \\
3.97-4.25\end{array}$ & $\begin{array}{l}1.6 \\
1.8\end{array}$ & 。 & $\begin{array}{l}2.29 \\
4: 04\end{array}$ & $\begin{array}{l}2.16-2.35 \\
3.93-4.29\end{array}$ & $\begin{array}{l}2.1 \\
1.7\end{array}$ \\
\hline
\end{tabular}




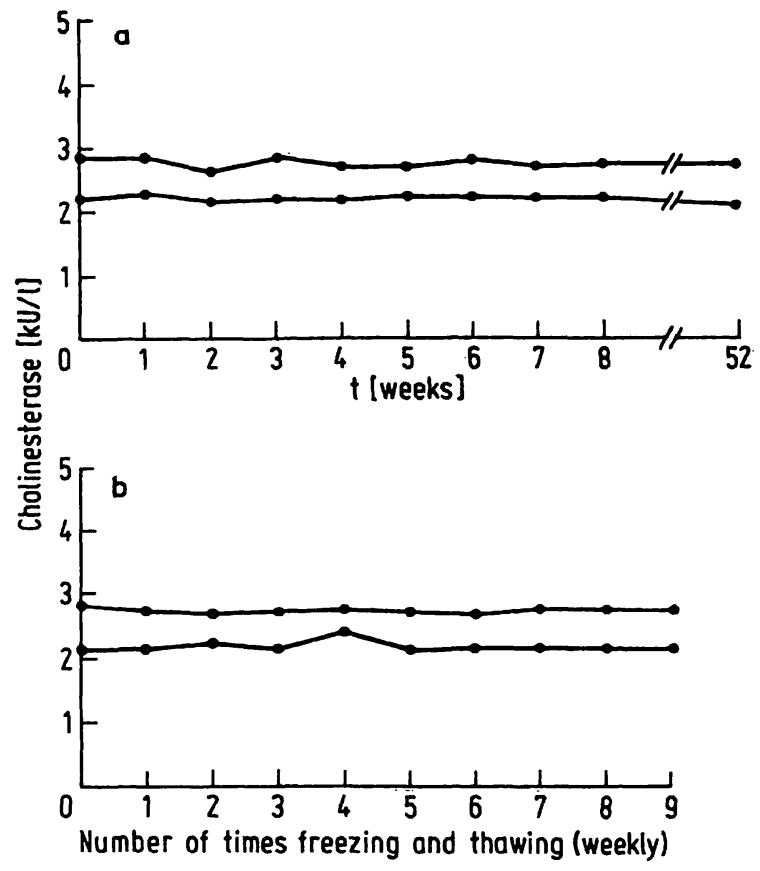

Fig. 3a. Influence of storage over 52 weeks at $-20^{\circ} \mathrm{C}$ in two experiments.

Fig. 3b. Influence of deep freezing and thawing at weekly intervals for 9 weeks, in two experiments.

Tab. 2. Cholinesterase catalytic concentration in serum of healthy controls (substrate: acetylthiocholine iodide, S. D.: standard deviation).

\begin{tabular}{lll}
\hline $\mathrm{n}$ & Males & Females \\
& 36 & 41 \\
\hline Mean $(\mathrm{kU} / \mathrm{l})$ & 3.11 & 2.50 \\
S. D. $(\mathrm{kU} / \mathrm{l})$ & $0.5 \overline{7}$ & 0.43 \\
Range $(\mathrm{kU} / \mathrm{l})$ & $1.80-4.40$ & $1.60-3.50$ \\
\hline
\end{tabular}

\section{References}

1. Evans, D. B. \& Lehmann, H. (1971) Lancet I, 1040-1044.

2. Silk, E., King, J. \& Whittaker, M. (1979) Añn. Clin. Biochem. 16, 57-75.

3. Knolle, J. (1970) Klin. Wochenschr. 48, 1157-1168.

4. Sżász, G. (1968) Clin. Chim. Acta 19, 191-204.

5. Weber, H. (1966) Dtsch. Med. Wochenschr. 91, 1927-1932.

6. Prellwitz, W., Kapp, S. \& Müller, D. (1976) J. Clin. Chem. Clin. Biochem. 14, 93-97.
The catalytic concentration was significantly lower in females $(p<0.0001$, Wilcoxon two sample test) than in males.

\section{Discussion}

Serum cholinesterase activity can easily be determined in every service laboratory. The assay is relatively simple to perform, and takes only about two minutes.

For practical reasons it is advantageous that serum for cholinesterase determination can be preserved for long periods. The catalytic activity was unaffected by storage at $20^{\circ} \mathrm{C}$, at $4^{\circ} \mathrm{C}$ and by long term storage at $-20^{\circ} \mathrm{C}$. Even repeated freezing and thawing did not affect the catalytic concentration, an observation that has been reported earlier $(8,9)$. On the other hand, other investigators have reported a decrease of $30 \%$ (10).

Using acetylthiocholine iodide as substrate, the reference values we found in our population are in agreement with the values given in previous publications (4-6).

We also found a significantly lower activity in females than in males (6). This finding can possibly be explained by differences in hormonal status between the two sexes (11).

\section{Acknowledgement}

We wish to thank Mrs. J.G. van Bree-Riksman for providing secretarial assistance and Dr. G.N. de Ruyter for his assistance in the preparation of this paper. The figures were prepared by Mr. J. Brouwer.
7. Ellman, G. L., Courtney, K. D., Andres, V. \& Featherstone, R. M. (1961) Biochem. Pharmacol. 7, 88-95.

8. Juul, P. (1967) Clin. Chem. 13, 416-422.

9. Turner, J.M., Hall, R.A., Whittaker, M. \& Kricka, L.J. (1984) Ann. Clin. Biochem. 21, 363-365.

10. Johnston, D.G. \& Huff, W. C. (1965) Clin. Chem. 11, $729-732$.

11. Den Blaauwen, D. H., Poppe, W. A. \& Tritschler, W. (1983) J. Clin. Chem. Clin. Biochem. 21, 381-386.

\author{
J. R. Huizenga \\ Hepatochemical Laboratory \\ Division of Hepatology \\ Department of Medicine \\ State University Hospital \\ Oostersingel 59 \\ NL-9713 EZ Groningen
}


